\title{
Co-incineration of Large Quantities of Alternative Fuels in a Cement Kiln - the Problem of Air Pollutant Emissions**
}

\section{Introduction}

The origins of co-incineration of alternative fuels in kilns for the production of cement clinker go back to the beginning of the 70's of the twentieth century, but originally the cement industry was used for the thermal utilization of only small amounts of liquid hazardous waste (including solvent derived fuels and waste petroleum derivatives), municipal waste (including refuse derived fuels), used tires (including tire derived fuels), sewage sludge and other solid waste [1-6]. At the same, as substitute fuels, coal sludge, oil shale, petroleum coke and biomass were used [7-9].

The use of alternative fuels brings economic and environmental benefits. They result from the reduction in consumption of non-renewable energy sources (fossil fuels), the possibility to safely dispose of problem waste and the recovery of energy from waste (or waste-derived fuels), as well as the reduction of global emission of air pollutants and greenhouse gases (including $\mathrm{CO}_{2}$ ), as compared to the incineration of this waste in incineration plants [9-11].

The maximum degree of substitution of primary fuels (coal, coke and heavy fuel oil) with alternative fuels in traditional cement kilns with a preheater (without a precalciner) is about $30 \%$, while in a precalciner itself with an additional furnace it can reach up to $100 \%$ [12]. In the kilns with a precalciner, usually up to $65 \%$ of the total fuel input energy is supplied through the calciner, and a minimum of 35\% through the main kiln burner. Taking this into account, in properly designed modern dry-process cement kilns, it is possible to achieve the share of alternative fuels in the kiln heat balance at the level of at least $75 \%$. This is extremely important as energy costs in the cement industry account for around $30-40 \%$ of production costs (excluding capital expenditure) [13].

\footnotetext{
* AGH University of Science and Technology, Faculty of Mining Surveying and Environmental Engineering, Department of Environmental Management and Protection, Krakow, Poland

** The paper has been prepared within the scope of the AGH UST statutory research no. 11.11.150.008
} 
Unquestionable economic benefits stimulated widespread use of all alternative fuels in the cement clinker burning process, also in the Polish cement industry [14, 15]. For example, in 2001-2009 the heat yield of alternative fuels in cement kilns in Poland increased 18 times (Fig. 1). According to the data from the Polish Cement Association [15], currently the cement industry in Poland consists of 13 plants (in 9 major cement groups) with the production of cement at around 15-19 million $\mathrm{Mg} /$ year in the last few years and an average annual heat consumption for the clinker burning continued at the level of 3500-3700 MJ/Mg of clinker.

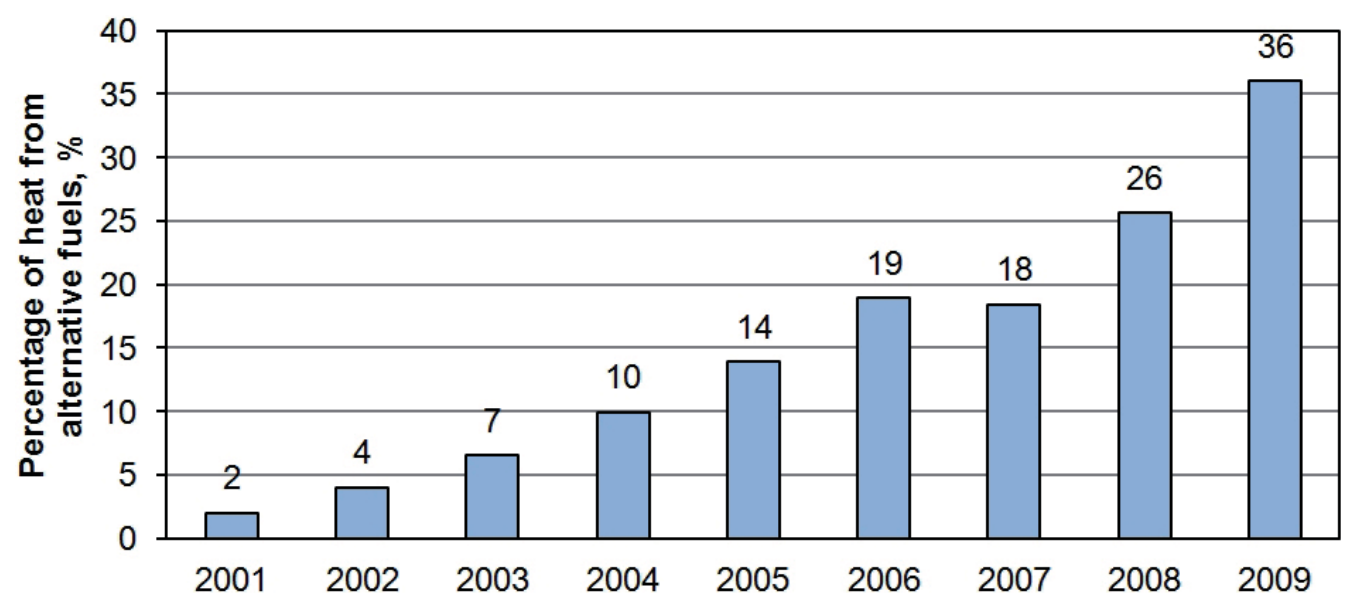

Fig. 1. Heat yield of alternative fuels in the cement industry in Poland in the years 2001-2009

Source: [15]

Due to the gradually increasing co-incineration of alternative fuels in cement kilns observed in Poland, a question is raised of the extent to which this translates into changes in the emission of pollutants into the air. The assessment of the impact of alternative fuels in dry-process cement kilns on the emission level of basic air pollutants, with the heat yield from alternative fuels reaching $20 \%$, has been presented in the works [16-19]. Research on emissions of heavy metals as well as polychlorinated dibenzo-p-dioxins and furans for the greater parameter variability of the kiln and the types of co-incinerated fuels and wastes, were in turn carried out by S. Zemba et al. [20]. As it is apparent from these and other studies, the type and amount of the co-incinerated alternative fuels usually have very little effect on the amount of air pollutant emissions. However, in these studies, the average degree of substitution of primary fuels with alternative fuels did not exceed $30 \%$.

This paper presents an analysis of changes in the size of emissions of air pollutants from dry-process cement kiln, covering a period of the last 5 years (1998-2012) with an average annual yield of heat from alternative fuels ranging from $43.5 \%$ to $78.5 \%$. 


\section{Characteristics of the Study Object}

The object of the study was the Chełm cement plant belonging to the group CEMEX Poland Sp. z o.o., located in the province of Lublin (Poland), on the outskirts of the town of Chełm. This plant produces clinker and cement. The clinker installation, operating on the dry process, includes a short cement kiln, with single three-stage cyclone heat exchanger and SLC calciner, which is a separate combustion chamber. The selected installation parameters have been comprised in Table 1, and the control diagram has been presented in Figure 2 [21, 22].

Cement kiln installation consists of the following devices:

- the devices for preparing and charging feedstock,

- external heat exchangers,

- the main kiln (rotary kiln),

- sintered clinker cooler,

- the devices for preparing and charging fuels,

- the devices for dedusting the kiln and the cooler off-gases.

Table 1. Technical parameters of the devices in the kiln installation

\begin{tabular}{|l|c|c||}
\hline \multicolumn{1}{|c|}{ Parameter } & Unit & Value \\
\hline \hline Maximum capacity of the system & Mg/day & 7000 \\
\hline Rotary kiln dimensions (length $\times$ diameter) & $\mathrm{m}$ & 4 \\
\hline Average slope of the kiln in relation to the level & ${ }^{\circ}$ & $1250-1450$ \\
\hline Temperature in the feedstock sintering zone & ${ }^{\circ} \mathrm{C}$ & $700-800$ \\
\hline Temperature in the drying zone & ${ }^{\circ} \mathrm{C}$ & 112 \\
\hline Clinker cooler grate surface & $\mathrm{m}^{2}$ & $24 \times 7.4$ \\
\hline Calciner dimensions (height $\times$ diameter) & $\mathrm{m}$ & 900 \\
\hline Calcination temperature & ${ }^{\circ} \mathrm{C}$ & 3 \\
\hline Number of stages of cyclone heat exchanger & - & 7.8 \\
\hline Diameter of a single cyclone in the heat exchanger & $\mathrm{m}$ & \multicolumn{2}{c||}{} \\
\hline
\end{tabular}

Exhaust gases from the rotary kiln, after giving out of the heat in the cyclone exchanger and drier-crusher, were originally dedusted in the electrostatic precipitator. Since May 2008, instead of the electrostatic precipitator, pulse-jet fabric filter has been used, equipped with 6,000 high temperature filter bags made of fiberglass. Gases from the clinker cooler are dedusted in the electrostatic precipitator.

The discussed installation complies with the requirements of co-incineration plants under the Directives 2000/76/UE 2010/75/EC and regulations which are binding in Poland [23-25]. Co-incineration of alternative fuels with technological fuel (coal) has taken place in the Chełm cement plant since 2001, and the obtained energy is used to produce clinker. 


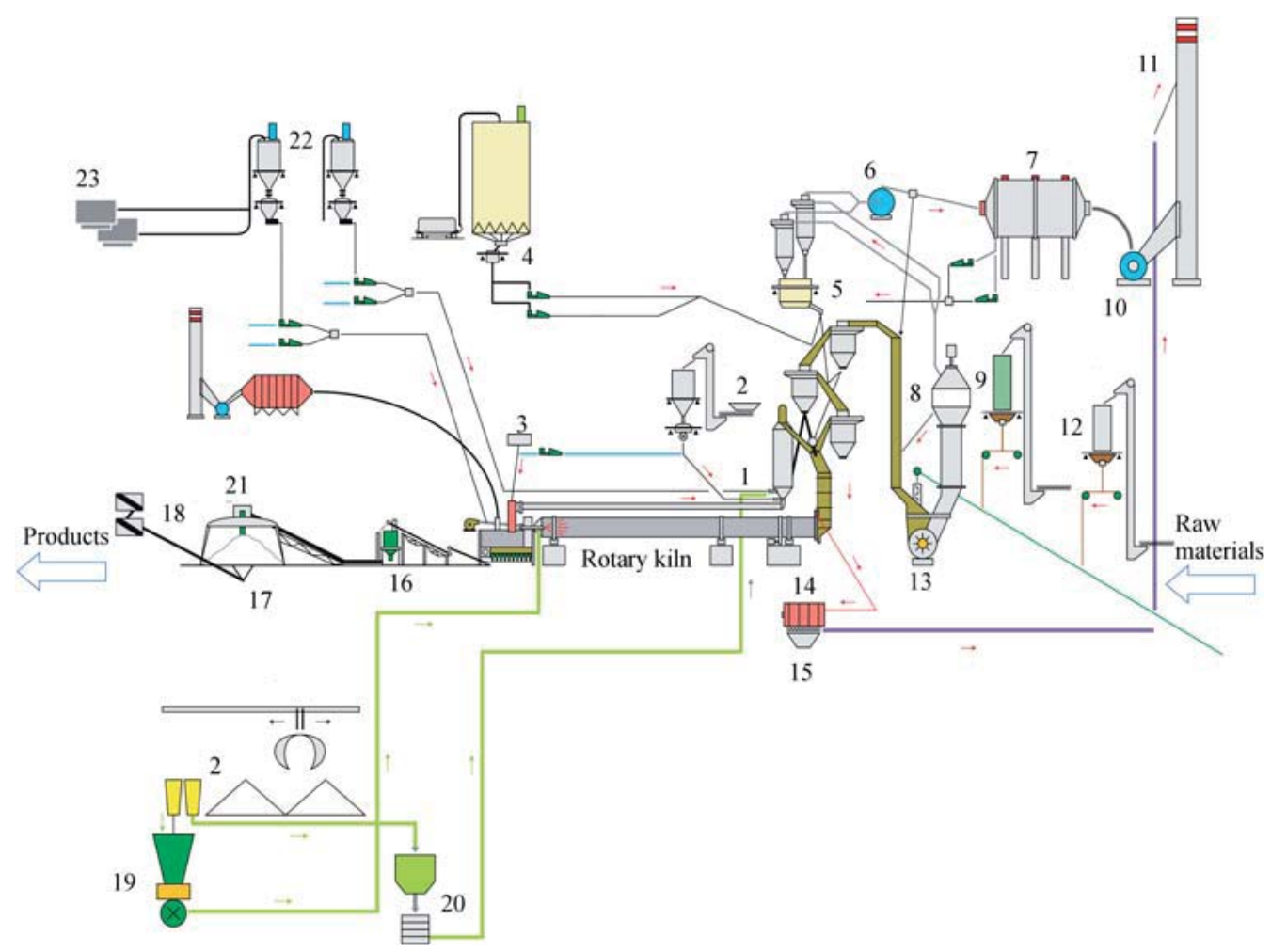

Fig. 2. Technological scheme of the cement kiln at Chełm cement plant.

Description: 1 - calciner, 2 - alternative fuels, 3 - liquid alternative fuels, 4 - multifeeder, 5 - first cyclone, 6 - fan, 7 - fabric filter, 8 - separator, 9 - silica, 10 - exhaust fan, 11 - stack, 12 - siderite, 13 - drier-crusher, 14 - by-pass, 15 - BPD loading, 16 - clinker tank, 17 - open storage, 18 - redlers, 19 - AF pfister, 20 - multifeeder, 21 - clinker aisle, 22 - coal siloses, 24 - bowl mill

Source: own work based on [21]

In the installation of the rotary kiln different types of alternative fuels are used [21, 26]:

- energetic light fractions segregated from municipal and industrial waste,

- tires,

- dried municipal sewage sludge,

- meat-and-bone meal,

- biomass (hay, straw),

- liquid waste (e.g., a mixture of oils, solvents, etc.).

The greatest share in the amount of burnt alternative fuels (about 90\% by weight) have refuse derived fuels (RDF), which are waste labelled with the code 191210. Quality requirements for this type of fuel set out by Chełm cement plant have been presented in Table 2 . 
Table 2. Quality requirements for alternative fuel with the waste code 191210 set out by Chełm cement plant

\begin{tabular}{|l|c|c||}
\hline \multicolumn{1}{|c|}{ Parameter } & Unit & Value \\
\hline \hline Fragmentation & $\mathrm{mm}$ & $<30$ \\
\hline Lower heating value & $\mathrm{kJ} / \mathrm{kg}$ & $\begin{array}{c}>22,000 \text { (rotary kiln) } \\
>17,000 \text { (calciner) }\end{array}$ \\
\hline Humidity & $\%$ & $<15$ \\
\hline Chlorine content & $\%$ & $<0.7$ (max 1) \\
\hline Sulphur content & $\%$ & $<1.0(\max 1.5)$ \\
\hline Ash content & $\%$ & $<5$ \\
\hline The content of non-flammable materials & $\%$ & $<100$ \\
\hline The content of heavy metals $(\mathrm{Hg}, \mathrm{Th}, \mathrm{Cd})$ & $\mathrm{mg} / \mathrm{kg}$ & $>50$ \\
\hline Flash point & ${ }^{\circ} \mathrm{C}$ & $<15$ \\
\hline \hline
\end{tabular}

Source: [22]

Alternative fuels with lower calorific value are burnt in the calciner at temperatures of $1000-1100^{\circ} \mathrm{C}$. More caloric fuels are fed with the coal to the burner of the main kiln and incinerated in the area of the highest temperatures, which in the gas phase reach $2000^{\circ} \mathrm{C}$.

The entire technological process is subject to monitoring. Due to the fact that waste is co-incinerated as well, in order to verify the compliance with the emission limit values, on the emitter of the cement kiln continuous monitoring was applied of concentrations of such substances such as:

- nitrogen oxides $\left(\mathrm{NO}_{\mathrm{x}}\right)$,

- sulphur dioxide $\left(\mathrm{SO}_{2}\right)$,

- total dust,

- carbon monoxide (CO),

- hydrogen chloride $(\mathrm{HCl})$,

- hydrogen fluoride (HF),

- total organic carbon (TOC).

In addition, twice a year, there are also carried out periodic measurements of emission size of heavy metals ( $\mathrm{Hg}, \mathrm{Cd}, \mathrm{Tl}, \mathrm{Sb}, \mathrm{As}, \mathrm{Pb}, \mathrm{Cr}, \mathrm{Co}, \mathrm{Cu}, \mathrm{Mn}, \mathrm{Ni}$ and $\mathrm{V}$ ) as well as polychlorinated dibenzo-p-dioxins and furans (PCDD/Fs).

All measurements are carried out in accordance with the applicable reference methodologies and they are related to the relevant emission limit values (Tab. 3) [23-25]. 
Table 3. Emission limit values for kilns for the production of cement clinker, in which waste is co-incinerated

\begin{tabular}{|c|c|c|}
\hline No. & Type of a substance & Emission limit values, $\mathrm{mg} / \mathrm{m}^{3}$ a) \\
\hline \hline 1 & Total dust & 10 \\
\hline 2 & $\mathrm{HCl}$ & 1 \\
\hline 3 & $\mathrm{HF}$ & $500(800)^{\mathrm{b})}$ \\
\hline 4 & $\mathrm{NO}_{\mathrm{x}}(\mathrm{as} \mathrm{NO})^{2}$ & $50^{\mathrm{c}}$ \\
\hline 5 & $\mathrm{SO}_{2}$ & $10^{\mathrm{c}}$ \\
\hline 6 & $\mathrm{TOC}$ & $2000^{\mathrm{d})}$ \\
\hline 7 & $\mathrm{CO}$ & 0.05 \\
\hline 8 & $\mathrm{Cd}+\mathrm{Tl}$ & 0.05 \\
\hline 9 & $\mathrm{Hg}$ & 0.5 \\
\hline 10 & $\mathrm{Sb}+\mathrm{As}+\mathrm{Pb}+\mathrm{Cr}+\mathrm{Co}+\mathrm{Cu}+\mathrm{Mn}+\mathrm{Ni}+\mathrm{V}$ & $0.1^{\mathrm{e})}$ \\
\hline 11 & $\mathrm{Dioxins}$ and furans $\left[\mathrm{ng} / \mathrm{m}^{3}\right]^{\mathrm{a}}$ & \\
\hline
\end{tabular}

a) standardized at $101.3 \mathrm{kPa}, 273 \mathrm{~K}$, dry gas, $10 \% \mathrm{O}_{2}$;

b) the value of $800 \mathrm{mg} / \mathrm{Nm}^{3}$ applies to the existing installations, in accordance with the laws in force in Poland [25] and the kilns type "Lepol" and long rotary kilns (before 01.01.2016) according to [23];

c) emission limit values may not be applied in cases where these substances do not result from the co-incineration of waste;

d) emission limit values resulting from the regulations binding in Poland [25];

e) in relation to the toxicity factor I-TEQ.

Source: [23-25]

\section{Study Results and Discussion}

An analysis of the measurement results of emission size of air pollutants was conducted for the years 2008-2012. During this period, the share of co-incinerated alternative fuels in the heat balance of the cement kiln in the Chełm cement plant nearly doubled, reaching in 2012 an unprecedented in Poland level of 78.5\% (Fig. 3). The remaining part of the paper focuses on the assessment of the emission of pollutants into the air with such a large share of the co-incinerated alternative fuels.

In order to assess the level of emissions into air, the continuous monitoring results were used $\left(\mathrm{NO}_{x^{\prime}} \mathrm{SO}_{2}\right.$, total dust, $\mathrm{CO}, \mathrm{HCl}, \mathrm{HF}$ i TOC) as well as the periodic ones (heavy metals and PCDD/Fs). 


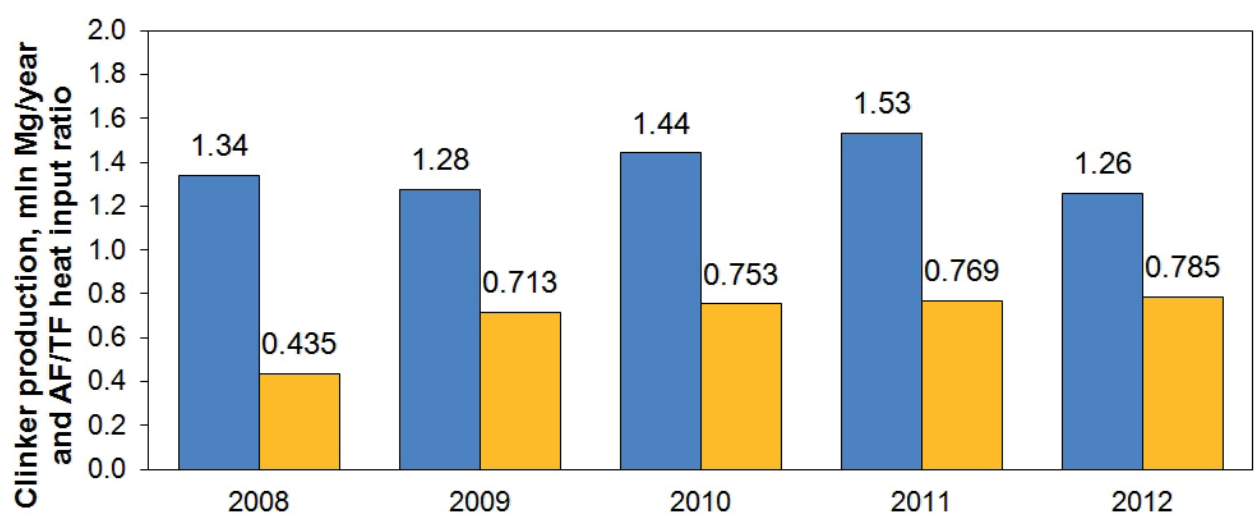

$\square$ Clinker production, $\mathrm{mln} \mathrm{Mg} / \mathrm{year}$

$\square$ Alternative fuel (AF) heat input as a share of total fuel (TF) heat input

Fig. 3. Clinker production and overall share of alternative fuels in the heat balance of the cement kiln at Chełm cement plant in the years 2008-2012

Figures 4 and 5 present the concentrations of substances in the gases emitted into the air in individual years with respect to the relevant emission limit values, however, in the case of substances measured in a continuous manner (Fig. 4) these are annual mean values, and in the case of substances measured periodically (Fig. 5) - the mean values of the two measurements carried out each year. As it is apparent from the presented data, in the analyzed period the mean concentrations of most of the substances in question were below the emission limit values referring to the waste co-incineration process specified for them.

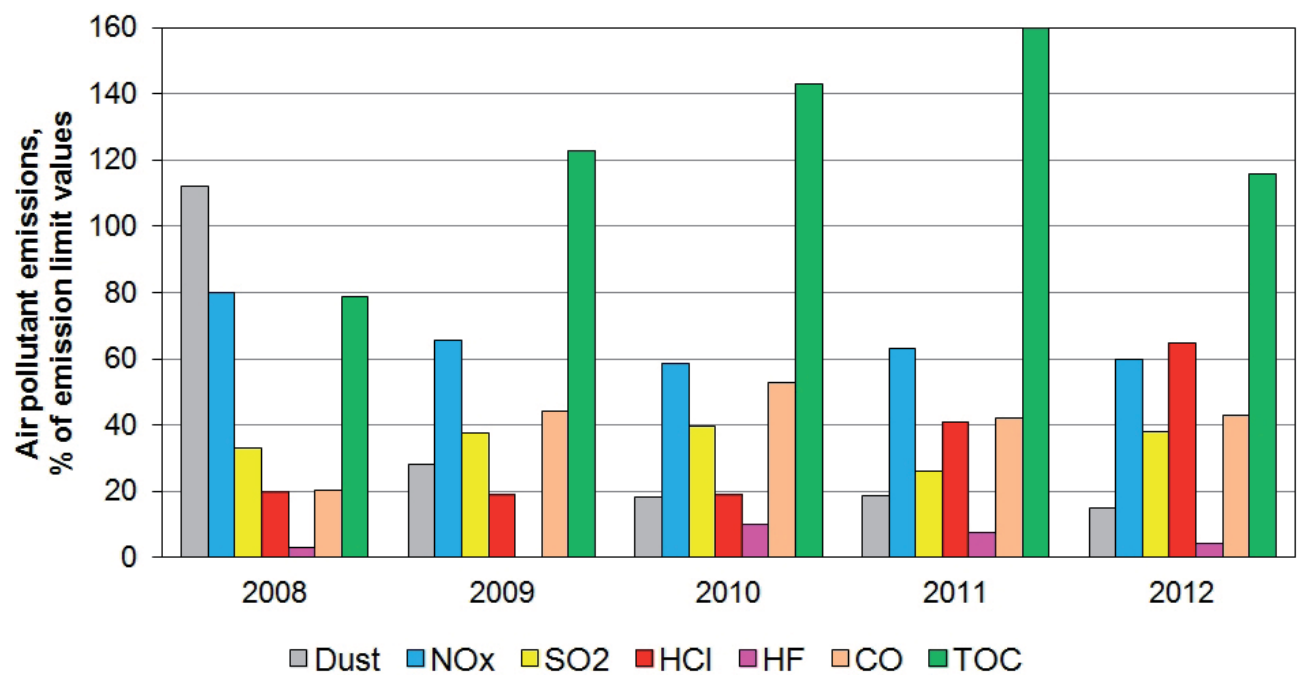

Fig. 4. Comparison of the results of continuous measurements of air pollutant emissions in the years 2008-2012 (mean annual concentrations) to the binding emission limit values 


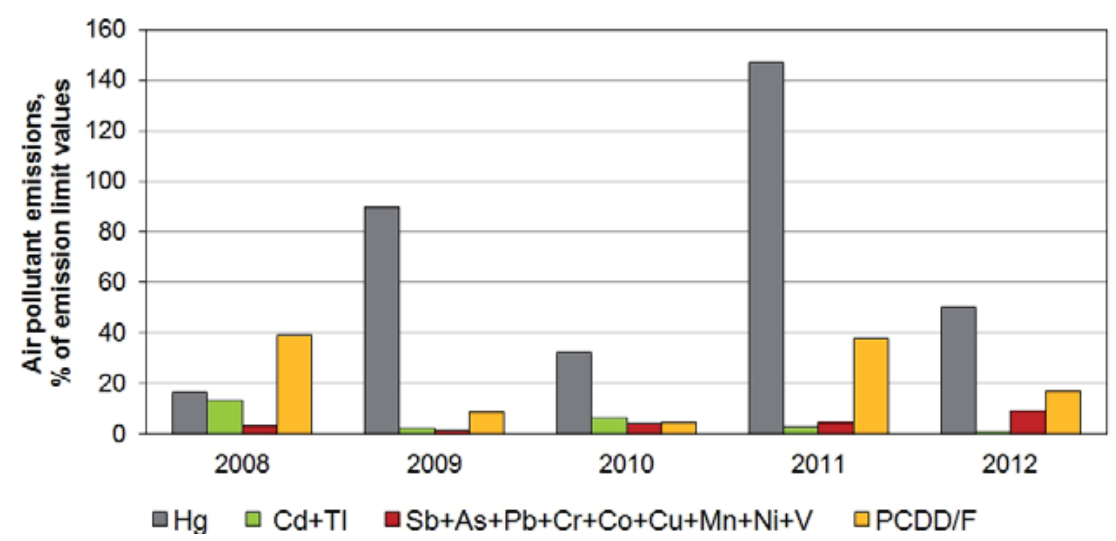

Fig. 5. Comparison of the results of periodic measurements of air pollutant emissions carried out in the years 2008-2012 (mean concentrations of two measurements per year) to the binding emission limit values

In the case of the total dust, the emission limit value was not complied with only in 2008, during which the dust collector was exchanged for a more effective one (electrostatic precipitator was replaced with a fabric filter). After the exchange, the total dust emission was markedly reduced and since then it has remained at an average level of $15-30 \%$ of the emission limit value. The use of high-performance dust collector was certainly the main factor that resulted in the average concentrations of heavy metals (except mercury) in the emitted gases during periodic measurements being below $15 \%$ of the emission limit values, and the mean concentrations of PCDD/Fs below $40 \%$ of the emission limit value. Above-limit mercury emissions were noticed during the periodic measurements carried out in 2011 and it was probably associated with an increased load of mercury allowed into the process of clinkering during the measurements (one of the mercury sources in this process may be, e.g. sewage sludge, whose share in the incineration of alternative fuels was subject to significant fluctuation). In the case of all other analyzed measurements, mercury concentrations were at $16-90 \%$ of the emission limit values.

An additional problem is posed by elevated annual concentrations of TOC, which have significantly increased after 2008, i.e. after a significant increase in the proportion of the co-incinerated alternative fuels. Taking this into account, in theory, it is difficult to assume that these substances are not formed as a result of co-incineration. Nevertheless, the annual average concentration of TOC in the dry gas at the level of several milligrams per cubic meter, at the maximum daily concentrations for the test kiln of $30 \mathrm{mg} / \mathrm{m}^{3}$ (standardized at $101.3 \mathrm{kPa}, 273 \mathrm{~K}$, dry gas, $10 \% \mathrm{O}_{2}$ ) [27], do not differ from the typical emissions of TOC for this type of process known from this one, or other, cement plant, with small quantities of the co-incinerated waste [13, 18, 22]. European Union [24] and national [25] regulations allow here for the possibility of derogation in the scope of the exceeded the emission limit values and disregard of this fact by the competent authority. 
For the continuously monitored substances, the mean annual emission factors were determined as well, which were related to clinker production (Tab. 4). The impact of percentage of heat from alternative fuels on the values of these emissions factors has been presented in Figure 6.

Table 4. Average air pollutant emission factors for a cement kiln at the Chełm cement plant in the years 2008-2012

\begin{tabular}{|c|c|c|c|c|c|c||}
\hline \multirow{2}{*}{ Year } & \multicolumn{7}{|c||}{ Emission factor $[\mathrm{kg} / \mathrm{Mg}$ clinker $]$} \\
\cline { 2 - 7 } & Dust & $\mathrm{NO}_{\mathrm{x}}\left(\mathrm{NO}_{2}\right)$ & $\mathrm{SO}_{2}$ & $\mathrm{HCl}$ & $\mathrm{CO}$ & TOC \\
\hline \hline 2008 & 0.0843 & 1.60 & 0.0415 & 0.0050 & 1.02 & 0.0198 \\
\hline 2009 & 0.0244 & 1.52 & 0.0544 & 0.0055 & 2.55 & 0.0357 \\
\hline 2010 & 0.0156 & 1.33 & 0.0562 & 0.0054 & 3.00 & 0.0406 \\
\hline 2011 & 0.0159 & 1.44 & 0.0369 & 0.0117 & 2.40 & 0.0455 \\
\hline 2012 & 0.0130 & 1.39 & 0.0553 & 0.0188 & 2.50 & 0.0336 \\
\hline
\end{tabular}
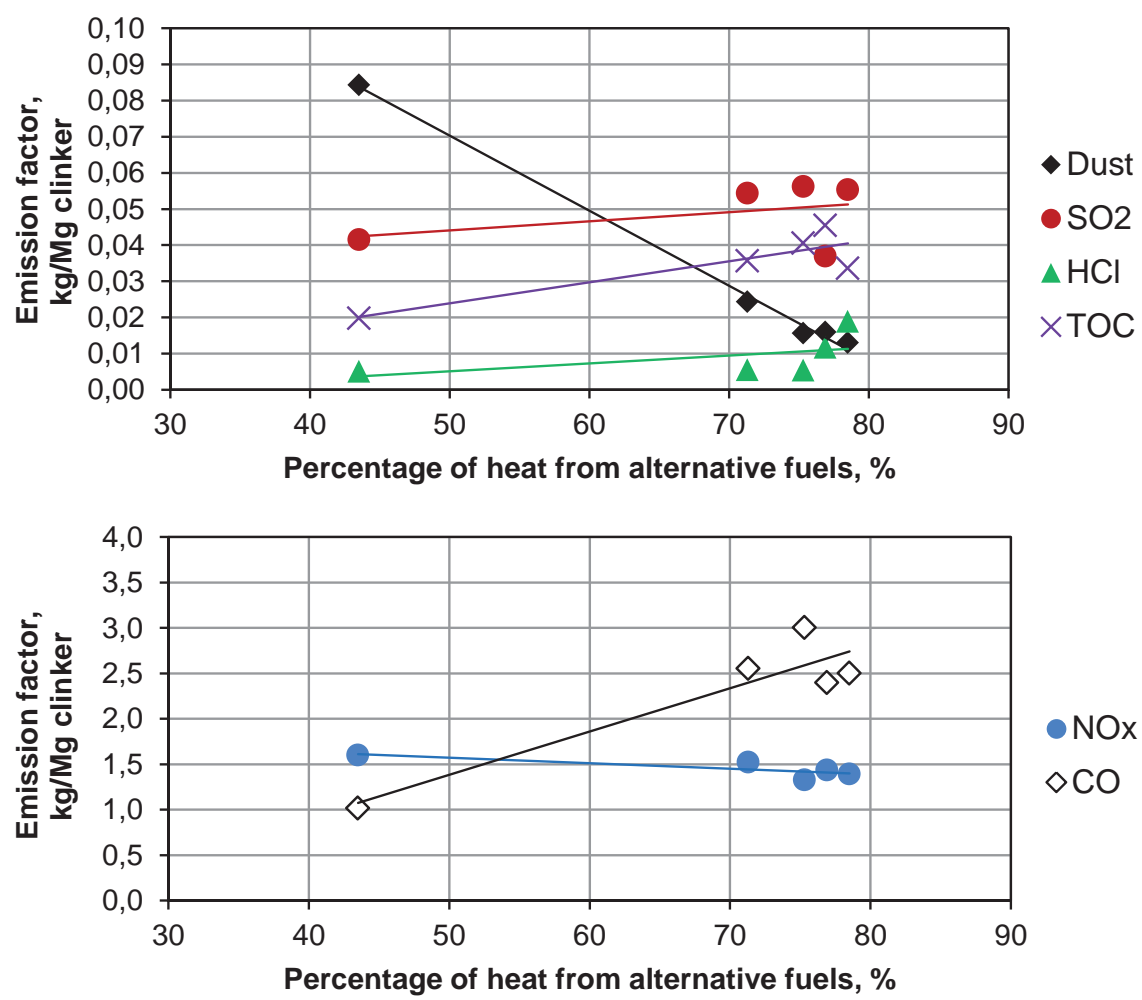

Fig. 6. The relationship between heat yield from alternative fuels in the tested cement kiln and mean annual factors of air pollutant emissions: a) dust, $\left.\mathrm{SO}_{2}, \mathrm{HCl}, \mathrm{TOC} ; \mathrm{b}\right) \mathrm{NO}_{\mathrm{x}}\left(\right.$ as $\left.\mathrm{NO}_{2}\right)$ and $\mathrm{CO}$ 
Taking into account the fact that in 2008 the yield of heat of alternative fuels amounted to $43.5 \%$, and since 2009 already more than $70 \%$, the observed since 2009 reduction in a mean $\mathrm{NO}_{x}$ emission factor from the cement kiln (by about 5-17\%) can be attributed to the increase in the amount of the co-incinerated fuels. The observed in 2008-2012 significant decrease in the mean dust emission factor, results mainly from the replacement of electrostatic precipitator with a fabric filter and the optimization of its operation. In the case of $\mathrm{SO}_{2}$, the observed fluctuations in emission factors in different years do not depend on the share of alternative fuels in the cement kiln heat balance either, which confirms the conclusions from the other studies $[11,17,18]$. However, the increase in the average emission factor of $\mathrm{HCl}$ (observed in 2011-2012) results more from the likely increase in the amount of chlorine in the incinerated alternative fuels (and possibly also in other fuels and raw materials) rather than from the increase in consumption of these fuels, even compared to 2008. The proof may lie in the fact that the increased emission factors of $\mathrm{HCl}$ was not observed in the years 2009-2010, in which the amount of the alternative fuels was already much higher than in 2008.

On the other hand, in the period of the increased heat yield of alternative fuels (2009-2012), a significant increase in the emission factors of CO and TOC occurred, compared to 2008, which could theoretically indicate a relationship to the amount of the co-incinerated alternative fuels (including waste). Any confirmation of this trend, however, requires further study, since the technological process of burning cement clinker itself can be characterized by the increased and variable emission of the above-mentioned substances.

\section{Conclusions}

Based on the conducted study, the following conclusions were drawn:

1. In a modern dry-process cement kiln (with a precalciner), it is possible to co-incinerate large quantities of various alternative fuels (including waste). The total yield of heat from alternative fuels can reach up to $80 \%$, as it was the case in a Chełm cement plant in 2012.

2. Even with such a large share of alternative fuels in the kiln heat balance, in the case of an installation equipped with a multi-stage cyclone heat exchanger and high-efficiency dust-collecting device (fabric filter), air pollutant emissions above limit values specified for the co-incineration of waste in the European Union are usually not observed.

3. The exception can be total organic carbon (TOC) and mercury (Hg), for which compliance with the emission limit values (standardized at $101.3 \mathrm{kPa}, 273 \mathrm{~K}$, dry gas, $10 \% \mathrm{O}_{2}$ ), amounting to 10 and $0.05 \mathrm{mg} / \mathrm{m}^{3}$ respectively, is not always the case. The problem of the above-limit mercury emissions can be relatively easily eliminated by reducing its content in the co-incinerated waste and other fuels. The increased TOC emission from the cement kiln (exceeding 10 
$\mathrm{mg} / \mathrm{m}^{3}$ ) usually occurs during the non-use of alternative fuels as well. This could become a basis for derogations with respect to the emission limit values for the co-incineration of waste by a competent environmental authority.

4. The increase in the amount of alternative fuels incinerated in a cement kiln may lead to a reduction in nitrogen oxides $\left(\mathrm{NO}_{\mathrm{x}}\right)$ emission, particularly resulting from a thermal mechanism (reduction of flame temperature as a result of using less calorific fuels). Further reduction of this emission, ensuring constant compliance with the target emission limit value of $500 \mathrm{mg} / \mathrm{m}^{3}$, however, requires the application of some flue gas deNOx technique, e.g. selective non-catalytic reduction (SNCR).

5. Much larger amounts of chlorine than in conventional fuels and raw materials brought in with alternative fuels carry the risk of the increased emissions of hydrogen chloride $(\mathrm{HCl})$. The quantity of chlorine should also be controlled due to a number of other adverse effects, which pose a threat to the technological process and the installation itself [13].

6. Using an electrostatic precipitator for dust removal from cement kiln exhausts does not guarantee compliance with dust emission standards, which is binding when co-incinerating waste $\left(30 \mathrm{mg} / \mathrm{m}^{3}\right)$. It is therefore recommended to use a filter dust collector (fabric or ceramic filter) for this purpose, in particular while co-incinerating large amounts of alternative fuels. A high-efficiency dust-collecting device significantly reduces the emission of pollutants adsorbed on the surface of the dust going up with the exhaust gases, including volatile heavy metals (especially $\mathrm{Cd}$ and $\mathrm{Tl}$ ), as well as dioxins and furans.

\section{References}

[1] Lauber J.D.: Burning chemical wastes as fuels in cement kilns. Journal of Air Pollution Control Association, vol. 32, no. 7, 1982, pp. 771-776.

[2] Bouse E.F., Kamas J.W.: Update on waste as kiln fuel. Rock Products, vol. 91, no. 4, 1988, pp. 43-47.

[3] Neumann E., Duerr M., Kreft W.: The substitution of fossil fuels in cement kilns. World Cement, 21, 1990, pp. 80-88.

[4] Siemering W.H., Parsons L.J., Lochbrunner P.: Experiences with Burning Waste. Rock Products, vol. 94, no. 4, 1991, 36-46.

[5] Herat S.: Protecting the environment from waste disposal: The cement kiln options. Environment Protection Engineering, vol. 32, no. 1-2, 1997, pp. 25-35.

[6] Ishikawa Y., Heart S.: Use of cement kilns for managing hazardous waste in developing countries. [in:] Karagiannidis A. (Ed.), Waste to Energy - Opportunities and Challenges for Developing and Transition Economies, Springer-Verlag, London 2012, pp. 137-155. 
[7] Kurdowski W.: Kierunki zmniejszania zużycia ciepła w dzisiejszym przemyśle cementowym. Część II. Cement-Wapno-Gips, nr 3, 1984, pp. 83-86.

[8] Paulin F.: Die Verbrennung von festen, alternativen Brennstoffen im Zementdrehofen und ihr Handling. ZGK International, no. 1, 1998, pp. 30-38.

[9] Chinyama M.P.M.: Alternative fuels in cement manufacturing. [in:] Manzanera M. (Ed.), Alternative Fuel, InTech, 2011, pp. 263-284, [on-line:] http:// www.intechopen.com.

[10] Kreft W.: Thermal residue disposal in cement works - comparison with other methods of waste treatment. ZKG International, no. 7, 1995, pp. 368-374.

[11] Sustainable cement production: Co-processing of Alternative Fuels and Raw Materials in the Cement Industry. CEMBUREAU, January 2009, [on-line:] http:// www.cembureau.be.

[12] Schneider M., Romer M., Tschudin M., Bolio H.: Sustainable cement production - present and future. Cement and Concrete Research, vol. 41, 2011, pp. 642-650.

[13] Reference Document on Best Available Techniques in the Cement, Lime and Magnesium Oxide Manufacturing Industries. European Commission, May 2010.

[14] Mokrzycki E., Uliasz-Bocheńczyk A., Sarna M.: Use of alternative fuels in the Polish cement industry. Applied Energy, vol. 74, 2003, pp. 101-111.

[15] Activity Reports and Brochures, Polish Cement Association, 2011-2012, [on-line:] http://www.polskicement.com.pl.

[16] Prisciandaro M., Mazziotti G., Veglió F.: Effect of burning supplementary waste fuels on the pollutant emissions by cement plants: a statistical analysis of process data. Resources, Conservation and Recycling, vol. 39, 2003, pp. 161-184.

[17] Conesa J.A., Gálvez A., Mateos F., Martín-Gullón I., Font R.: Organic and inorganic pollutants from cement kiln stack feeding alternative fuels. Journal of Hazardous Materials, vol. 158, 2008, pp. 585-592.

[18] Oleniacz R.: Assessment of the impact of using alternative fuels in a cement kiln on the emissions of selected substances into the air. [in:] Wandrasz J.W., Pikon K., Czekalska Z. (Ed.), Waste to Energy and Environment, Silesian University of Technology, 2010, pp. 37-49.

[19] Zemba S. et al.: Emissions of metals and polychlorinated dibenzo( $p$ )dioxins and furans (PCDD/Fs) from Portland cement manufacturing plants: Inter-kiln variability and dependence on fuel-types. Science of the Total Environment, vol. 409, 2011, pp. 4198-4205.

[20] Kara M.: Environmental and economic advantages associated with the use of RDF in cement kilns. Resources, Conservation and Recycling, 68, 2012, pp. 21-28.

[21] Zakład Cementownia Chełm. Deklaracja Środowiskowa za rok 2011. Cemex Polska Sp. z o.o., [on-line:] http://cemex.pl/file/EMAS_2012.pdf.

[22] Kasietczuk M.: Cementowania Chełm jako instalacja wspótspalania odpadów. AGH, Wydział Geodezji Górniczej i Inżynierii Środowiska, Katedra Kształtowania i Ochrony Środowiska, Kraków 2011 (M.Sc. thesis, unpublished). 
[23] Directive 2000/76/EC of the European Parliament and of the Council of 4 December 2000 on the incineration of waste. OJ L 332, 28.12.2000, p. 91.

[24] Directive 2010/75/EU of the European Parliament and of the Council of 24 November 2010 on industrial emissions (integrated pollution prevention and control). OJ L 334, 17.12.2010, p. 17.

[25] Rozporządzenie Ministra Środowiska z dnia 22 kwietnia 2011 r. w sprawie standardów emisyjnych z instalacji. Dz.U. z 2011 r., nr 95, poz. 558.

[26] Kasietczuk M., Oleniacz R.: Energetyczne wykorzystanie statych paliw wtórnych z odpadów (SRF) na przykładzie instalacji wspótspalania paliw w Cementowni Chetm. Materiały z X Konferencji „Dla miasta i środowiska - problemy unieszkodliwiania odpadów”, Warszawa 2012.

[27] Oleniacz R., Kasietczuk M.: Wpływ procesu wspótspalania odpadów w piecu cementowym na jakość powietrza. [in:] Wandrasz A.J. (red.), Paliwa z odpadów. Technologie tworzenia $i$ wykorzystania paliw z odpadów, Wyd. PZITS Oddział Wielkopolski, Poznań 2011, pp. 197-209. 